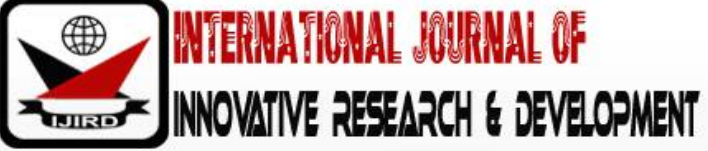

ISSN 2278 - 0211 (Online)

\section{The Ecological Effects of Wood Fuel Extraction on the Gazetted Forests within Koibatek Zone, Mau Forests Complex, Kenya}

Keith Kipng'etich Rono
Lecturer, Department of Environmental Studies, University of Kabianga, Kericho, Kenya
Raphael Achola Kapiyo
Associate Dean, School of Environment and Earth Sciences, Maseno University, Maseno, Kenya
Dr. Esnah Kerubo Bosire
Senior Lecturer, School of Environment and Earth Sciences, Maseno University, Maseno, Kenya

\begin{abstract}
:
Despite the importance of woodfuel in Kenya's economic development, the ecological effects of its extraction on forests (particularly gazette forests) remain unclear. Studies contradicts each other on effects of woodfuel extraction on forests with some indicating that it leads to loss of biodiversity and forest degradation while othersstating that woodfuel extraction is a forest cleaning activity and a part of good forest management. Little has been done to establish the area of forests lost due to woodfuel extraction as well as changes in distribution of preferred tree species from gazette forests in Kenya. The objective of this paper was to establish the ecological effects of woodfuel extraction on the gazette forests within Koibatek Zone, Mau Forests Complex-Kenya.Cross-sectional descriptive research design was adopted with all the 8 gazetteblocks within the Zone purposely selected. Stratified random sampling was used to select 384 woodfuel extractors and 8 FGDs were conducted each comprising of 10 participants. World Bank (2009) was used to convert volumes of woodfuel to equivalent forest cover required/consumed in gazetted forests from 2006-2014. Forest cover change for 2006-2014 was examined by analyzing satellite images acquired from the United States Geological Survey Global Visualization viewer.The estimated volume of woodfuel from gazetted forests between 2006 and 2014 was $260,746.1 \mathrm{~m}^{3}$ out of which $113,289.59 \mathrm{~m}^{3}$ was firewood and $147,456 \mathrm{~m}^{3}$ was charcoal. The forest cover lost due to woodfuel was equivalent mature trees contained in 3902.6ha of closedcanopy forests. This is equivalent to $7.6 \%$ of closed forests of the gazette blocks within Koibatek Forests Zone. About 13 tree species were preferred for woodfuel; 8 indigenous species and 5 exotic species. Indigenous trees preferred had reduced as indicated by $89 \%$ of extractors while distribution of exotic species remained constant as reported by $68 \%$ of extractors
\end{abstract}

Keywords: Ecological effects, wood fuel extraction, gazette, and closed-canopy cover

\section{Background}

A number of anthropogenic activities have led to destruction and general decrease of forests with increased woodfuel usage being identified as one of the biggest threat (Agarwala, 2006). Martinez-Alier (1995) established that demand for woodfuel destroys forests located near villages and towns in many countries of the world. For instance, in the arid regions of Asia, Africa and Latin America (i.e. the coast of Peru, the Sertôes in Brazil, Central America or the highlands of Andes), the main reason for deforestation is the use of woodfuel by the poor communities. FAO (2000) indicated that the annual rate of deforestation in Africa ranges between $0.75 \%$ in Angola and 2.2\% in Malawi. Soussan (1998) stated thatforest depletion has often been attributed to over reliance on woodfuel enhanced by factors such as local proximity and access, land tenure, and local management regimes. Abd'razack (2013) on its part stated that the ecological effects of woodfuel extraction in Africa include: loss of indigenous biodiversity, depletion of ecosystems and desertification of some regions. FAO (2006) established that over-reliance of woodfuel in rural areas has caused changes in forest ecosystems in various ways such as changes in distribution plant species, tree physiology and stability. This manifests itself in stand-level effects, as well as in major disruptions or disasters caused by more dramatic weather events. Therefore, protection and management of forests should assure that the ecological effects can be foreseen, managed and reduced to the greatest possible levels, in consideration of the long ecological cycle of forests. However, it is not clear from the studies how factors such as lumbering, animal grazing or weather events play out in destruction or depletion of global forests.

According to Abd'razack (2013), wood fuel extraction alone cannot be blamed for deforestation in developing countries of Africa; there are other factors such as timber logging and export to other nations particularly developed nations. UN ECOSOC (2017) added that there exist other drivers of deforestation that include: illegal or unsustainable logging, unmanaged forest fires, pollution, disease, pests, invasive alien species, land fragmentation and the impact of climate change, including severe weather events. Leach and Mearns (1998) also agrees by stating deforestation cannot be stopped even if the use of woodfuel is completely stopped. It is evident from studies that woodfuel extraction from forests is not solely responsible for reduction of forest cover and loss of biodiversity. Arnold et al (2003) also indicated that there 
exists some localized deforestation in most countries of the world, but depletion of forest cover on a large scale has not been found to be attributable to demand for firewood. This is because firewood is more often gathered from the roadside and trees outside forests, rather than from natural forests. The argument has been supported, in part, by ESMAP (2012) which stated that woodfuel harvesting is no longer considered the primary source of global deforestation, as it was in the 1970s. Currently, most deforestations results from clearing of land for farming to meet the food requirements of the rising population. Woodfuel supply to the dispersed rural populations is rarely an environmental threat nor is it globally unsustainable. A great portion of rural energy supply comes from trees outside forests, dead branches and logs, and agricultural residues.However, the studies did not isolate the ecological effects of woodfuel extraction on forests.

Nellie and Githiomi (2009) stated that continued loss of forests and associated resources in Kenya have causedfar reaching negative effects on the country's economy and welfare of citizens. According to Forest Society of Kenya (2010), extraction of woodfuel from fragile areas of Kenya has caused severe deforestation, biodiversity loss and reduction of food opportunities from natural vegetation. Therefore, supply of wood to meet household energy needs should be properly taken into account in forest planning and policy formulation.ESMAP (2012)pointed out that, concentrated industrial or urban demand for woodfuel in a situation of weak regulations can contribute to degradation of forests located around major centers of consumption. This arise because small rural industries (such as brick making), urban businesses (such as bakeries and restaurants), and traders of woodfuel for the urban household market are largely unregulated. Such woodfuel consumers tend to source wood at the lowest possible price, with little concern for supply-side sustainability. Du Plessis (1994) reported that woodfuel harvesters first collect all available dry wood on forest floor, and then proceed to break dead branches off live trees. When all available dead wood has been collected, the harvesters turn to cutting down live trees and branches. Therefore, woodfuelextraction eventually has ecological effects on forests. In spite of these, information on the linkage between thequantity of woodfuel extracted and forest cover lost and or distribution of tree species is missing for forests in Kenya.

Gevorkiantz and Olsen (1955) provided a conversion table of wood to the number of standing trees as shown in Table 1. For instance, one cord of firewood is made from one tree with a diameter of 22 inches (at the height of 4.5 feet) or 50 trees each having a diameter of 5 inches.

\begin{tabular}{|c|c|c|}
\hline $\begin{array}{c}\text { Tree Diameter (in inches) of } \\
\text { 4.5 feet in Height }\end{array}$ & $\begin{array}{c}\text { Number of Trees to make a } \\
\text { Cord of firewood }\end{array}$ & $\begin{array}{c}\text { Number of Cords per } \\
\text { Tree }\end{array}$ \\
\hline 5 & 50 & 0.02 \\
\hline 6 & 20 & 0.05 \\
\hline 7 & 12 & 0.08 \\
\hline 8 & 8 & 0.12 \\
\hline 9 & 6 & 0.17 \\
\hline 10 & 5 & 0.21 \\
\hline 11 & 4 & 0.25 \\
\hline 12 & 3.5 & 0.30 \\
\hline 14 & 2.5 & 0.40 \\
\hline 16 & 2 & 0.50 \\
\hline 18 & 1.5 & 0.65 \\
\hline 22 & 1 & 1.00 \\
\hline
\end{tabular}

Table 1: Table for Converting Number of Trees into Cords of Firewood Gevorkiantz and Olsen (1955)

Patmos (2005) stated that the table can be used to keep a running tally of the number of many trees to cut for the required number of wood stacks rather than waiting until the wood is all stacked (Table 4). However, the conversion table did not provide the average diameters of trees either within a natural forest or forest plantations making it difficult to be applied on forests whose information on the average Diameter at Breast Height (DBH) of its trees is unknown. World Bank (2009) stated that, the total annual charcoal consumption in Tanzania is estimated at 2650 tonnes per day produced from $82,192 \mathrm{~m}^{3}$ of wood using traditional kilns. This daily wood requirement is equivalent to that contained in 342.5 ha of forest. Although World Bank (2009) did not provide formulae for converting the amounts of charcoal (in tonnes) consumed into area of forest cover required for charcoal production, the statistics are applicable in converting the volumes of woodfuel to the equivalent area of forests cover lost during extraction.

The paper focused on Mau Forests Complex (MFC) which according to ENSDA (2005) has been the most degraded amongst Kenyan forests and its cover has receded drastically over time. MFC covers an area of 400,000 ha and forms the largest forest block in Kenya and the largest single block of closed-canopy forest in East Africa (KFS, 2014). Mau Forests Complex which is made up of 22 blocks of gazette forests, eight of which lies within Koibatek Forests Zone in Baringo County, Kenya. According to KFS-Koibatek (2011), the gazette forests of Koibatek Forests Zone are the most vulnerable to degradation within Mau Forest Complex due to high demand for woodfuel and other forest products such as timber and grass. The area of gazette forests of Koibatek Forests Zone is 51,007.7 ha; 27,996.5 ha being natural forests and 19,416.3 ha forests plantations (KFS-Koibatek, 2011). 


\subsection{Statement of the Problem}

Despite the importance of woodfuel in Kenya's economic development, the information on its ecological effects on forests (particularly government forests) is scarce. Studies contradicts each other on the effects of woodfuel extraction on forests with some studies indicating that woodfuel extractions leads to loss of biodiversity and forest degradation while other studies have indicated that woodfuel extraction is a forest cleaning activity and a part of good forest management. However, little has been done to establish the area of forests lost due to woodfuel extraction and changes in distribution of preferred tree species from gazette forests in Kenya. Therefore, the purpose of the paper was to establish the area of closed canopy forests lost due to woodfuel and changes in distribution of preferred tree species for wood fuelin the gazette forests.

\subsection{Objectives}

The main objective of the paper was to establish the ecological effects of woodfuel extraction on the Gazetted Forests within Koibatek Zone, Mau Forests Complex, Kenya. It specifically sought to: establish the volume of wood fuel extracted from gazette forests between 2006 and 2014 and convert it to the equivalent area of closed canopy cover of forest lost. In addition, the paper examined the effects of woodfuel extraction on distribution of preferred trees species.

\subsection{Justification}

The findings are useful to policy makers and managers in the forest sector providing information on the effects of wood energy on forest reserves. This will guide policy formulation and preparation of management plans for sustainable forest management through planned utilization of forest products. The findings will also guide future researches on utilization of products within gazette and private forests.

\subsection{Study Area}

The area of study was Koibatek Forests Zone which lies on Eastern part Mau Forests Complex between longitudes 35'35" and 35'15" and Latitudes 0'11" South and 0' 15" North. The Zone's gazetteforests cover an area of $510.08 \mathrm{~km}^{2}$ or $51,007.7$ ha which is approximately $20.12 \%$ covers of Eastern Mau having an area of 2,535 $\mathrm{km}^{2}$ or 253,500 ha (IUCN, 2008). According to KFS-Koibatek Zone (2011), the Zone comprises of eight (8) gazette forests blocks namely: Chemorgok, Chemususu, Narasha, Sabatia, Esageri, Maji Mazuri, Kiptuget and Koibatek forests. The main vegetation of the gazette forest blocks constitutes natural forest, grassland vegetation, and industrial plantation. Figure 1 shows the location of Koibatek Forests Zone in Map of Kenya and also indicates the boundaries of the eight gazette forests blocks within the Zone.

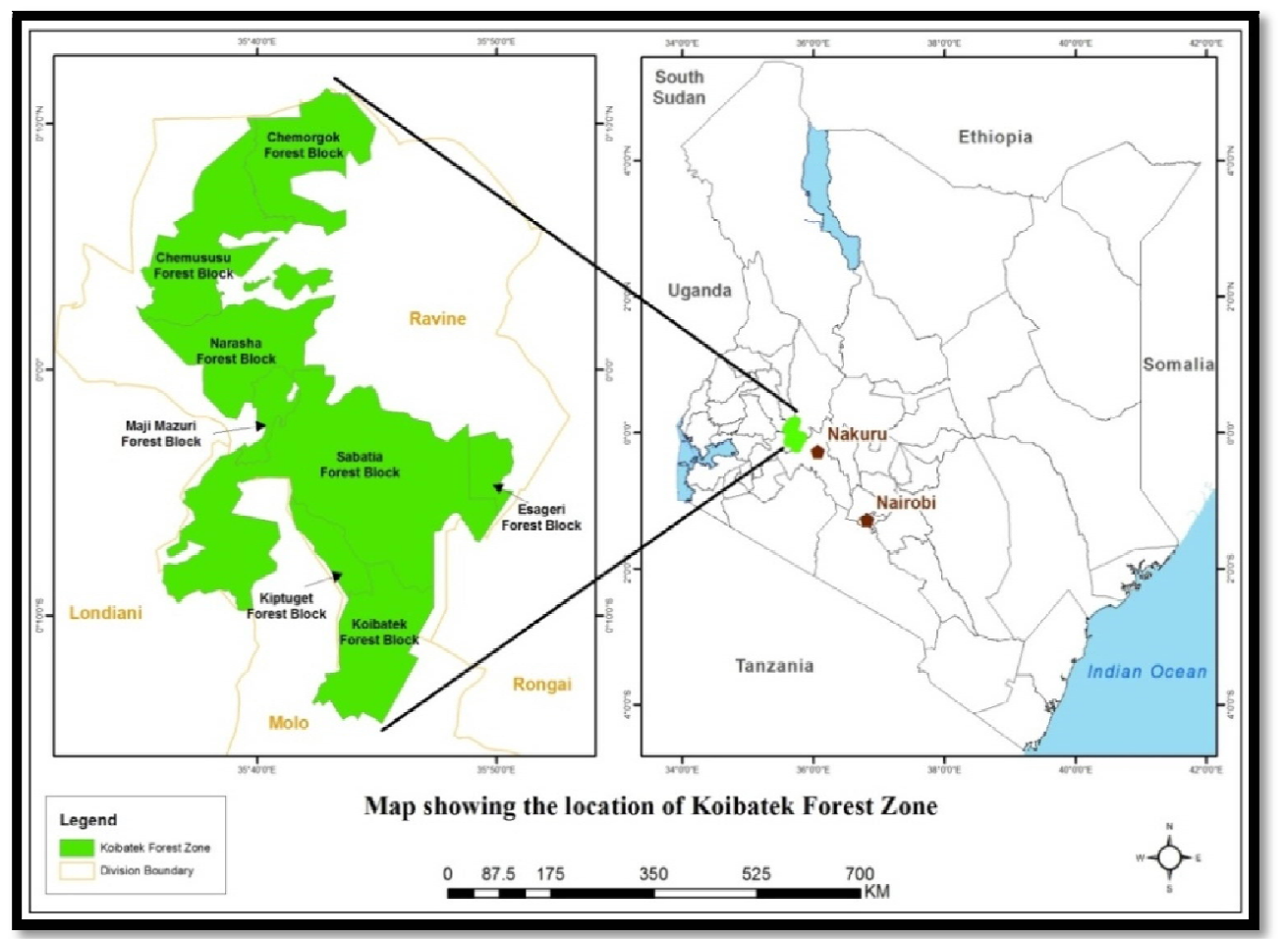

Figure 1: The Eight Gazette Forest Blocks within Koibatek Forests Zone Source: Kenya Forest Service (KFS), 2015

\section{Methodology}

A cross-sectional descriptive research design was adopted. Firstly, all the eight (8) gazette forests blocks within Koibatek Forests Zone was selected. The target population was 7,154 registered Community Forest Association (CFA) members which reflected the population of adjacent forest community of the gazette forests within the Zone. Kothari (2004) formula was applied to derive a sample of 384 members who were interviewed by administration of questionnaires. 8 Focused Group Discussions (FGD) were conducted each comprising of 10 participants in accordance 
with Escalada and Heong (2010) that stated that the optimum number of participants in a FGD should be 8 to 10. Volume of firewood extracted was estimated by examining the licensing profiles between 2006 and 2014 while volume of charcoal was estimated by establishing the number of producers; the number of bags produced within the period. World Bank (2009) was then used to convert the volume of woodfuel to equivalent forest cover required for the woodfuel extracted. Forest cover change over the period of between 2006 and 2014 was examined by acquiring and analyzing satellite imagesacquired from the United States Geological Survey (USGS) Global Visualization viewer website (www.glovis.usgs.gov). The satellite images acquired were for 2006, 2010 and 2014 in line with commencements of implementation of both Forest Act, 2005 and Energy Act, 2006; year 2010 due to the promulgation of Constitution of Kenya (2010) and, the year 2014 because of establishment of Kenya's Forest Policy, 2014.

\section{Results}

3.1. Forest Canopy Equivalent for Woodfuel Extracted Between 2006 and 2014

\subsubsection{Volume of Firewood Extracted between 2006 and 2014}

\begin{tabular}{|c|c|c|c|c|c|c|c|c|c|c|}
\hline \multirow{2}{*}{$\begin{array}{c}\text { Forest } \\
\text { Block }\end{array}$} & \multicolumn{8}{|c|}{ Annual Volume of Firew ood (M3) Between 2006 and 2014 } & \\
\cline { 2 - 11 } & 2006 & 2007 & 2008 & 2009 & 2010 & 2011 & 2012 & 2013 & 2014 & Total \\
\hline Chemorkok & 813.57 & 664.1 & 365.8 & 255.6 & 405.8 & 442.6 & 426.7 & 323.2 & 484.4 & $4,181.8$ \\
\hline Chemususu & 276.7 & 521.4 & 180.8 & 147.5 & 400.3 & 1972.1 & 2703.8 & 2363.3 & 2245.0 & $10,810.9$ \\
\hline Narasha & 3307.9 & 2132.2 & 517.2 & 2627.46 & 1763.0 & 2209.7 & 1196.21 & 788.4 & 711.1 & $15,253.2$ \\
\hline $\begin{array}{c}\text { Maji- } \\
\text { Mazuri }\end{array}$ & 3061.2 & 3625.5 & 1828.1 & 2631.9 & 1602.2 & 1315.1 & 3200.9 & 3560.0 & 1899.5 & $22,724.4$ \\
\hline Sabatia & 721.4 & 366.3 & 332.7 & 1190.6 & 465.5 & 177.5 & 466.6 & 99.2 & 329.2 & $4,149.0$ \\
\hline Esageri & 2970.7 & 3277.2 & 1429.0 & 604.5 & 1555.1 & 1757.9 & 2802.6 & 866.5 & 1623.2 & $16,886.7$ \\
\hline Koibatek & 1493.6 & 2888.9 & 1588.0 & 2613.7 & 6186.1 & 2277.4 & 8357.3 & 3814.7 & 2287.3 & $31,507.0$ \\
\hline Kituget & 1159.3 & 1363.7 & 300.6 & 653.9 & 548.7 & 622.9 & 1579.5 & 902.2 & 646.3 & $7,777.1$ \\
\hline Total & 13804.4 & 14839.3 & 6542.2 & 10725.2 & 12926.7 & 10775.2 & 20733.6 & $12,717.5$ & 10,226 & $113,290.1$ \\
\hline
\end{tabular}

Table 2: Estimated Volume of Firewood Extracted from Gazette Forests of Koibatek Zone from 2006 to 2014

Source: KFS, Koibatek (2015)

Table 2 indicated the total estimated volume of firewood extracted from the eight gazette forest blocks from 2006 to 2014 was $113,290.1 \mathrm{~m}^{3}$. Volumes within each of the blocks from the highest to the lowest were: Koibatek block (31,507 $\left.\mathrm{m}^{3}\right)$, Maji-Mazuri $\left(22,724.4 \mathrm{~m}^{3}\right)$, Esageri $\left(16,886.7 \mathrm{~m}^{3}\right)$, Narasha $\left(15,253.2 \mathrm{~m}^{3}\right)$, Chemususu $\left(10,810.9 \mathrm{~m}^{3}\right)$, Kiptuget $\left(7,777.1 \mathrm{~m}^{3}\right)$, Chemorgok $\left(4,181.8 \mathrm{~m}^{3}\right)$ and Sabatia $\left(4,149.0 \mathrm{~m}^{3}\right)$. Within the 9 year period, the highest annual volume of firewood extracted was $20,733.6 \mathrm{~m}^{3}$ in 2012 while the lowest annual volume was $6,542.2 \mathrm{~m}^{3}$ in 2008 .

\subsubsection{Estimated Volume of Charcoal between 2006 and 2014}

\begin{tabular}{|c|c|c|c|c|c|}
\hline \multirow{2}{*}{ Extraction Activity } & \multicolumn{6}{|c|}{ \% of the Number of Bags Produced at a Time } & \multirow{2}{*}{ Total } \\
\cline { 2 - 5 } & $0-1$ & $1-5$ & $6-10$ & $11-15$ & \\
\hline Firewood and Charcoal & 6.3 & 72.9 & 4.2 & 0.0 & 83.3 \\
\hline Charcoal only & 0.0 & 2.1 & 12.5 & 2.1 & 16.7 \\
\hline Total & 6.3 & 75.0 & 16.7 & 2.1 & 100 \\
\hline
\end{tabular}

Table 3: Table: Percentage of Number of Bags of Charcoal per a Production Event

Source: Field Survey, 2015

Table 3 shows that $83.3 \%$ of charcoal producers did the activity together with firewood collection while $16.7 \%$ were exclusively charcoal producers within gazette forests of Koibatek Zone. $75 \%$ of the charcoal producers made 1-5 bags of charcoal per event while $16.7 \%$ produced 6-10 bags of charcoal. Charcoal producers who made less than 1 bag of charcoal per event were $6.3 \%$ and those who produced $11-15$ bags were $2 \%$. Therefore, it was noted that, though charcoal production were illegal within gazette forests (KFS-Koibatek, 2015), most charcoal producers entered the gazette forests as firewood collectors only to secretly undertake charcoal burning illegally.

The amount of charcoal produced at any one time by the 48 charcoal producers interviewed within Koibatek Zone was found to be approximately 186.0 bags at a time (Table 4 ). 


\begin{tabular}{|c|c|c|c|}
\hline Number Of Bags At A Time & Frequency (F) & Mid-Points (X) & Fx \\
\hline $0-1$ & 3 & 0.5 & 1.5 \\
\hline $1-5$ & 36 & 3 & 108 \\
\hline $6-10$ & 8 & 8 & 64 \\
\hline $11-15$ & 1 & 13 & 13 \\
\hline & $\sum \mathrm{F}=48$ & & $\sum \mathrm{Fx}=186.5$ \\
\hline
\end{tabular}

Table 4: Number of Bags of Charcoal Produced at a Time from Koibatek Forests Zone

Source: Field Survey, 2015

On average, charcoal produced at any one time by one charcoal producer within Koibatek Forests Zone is approximately 3.9 bags (Equation 1 ).

Average number of bags at a time $=\left(\sum \mathrm{fx}\right) /\left(\sum \mathrm{f}\right)=(186.5) / 48=3.9$ bags of charcoal

Equation 1: Per Capita Charcoal produced

Given that approximately 895 charcoal producers operates within the entire Koibatek Forests Zone, then, the amount of charcoal produced at a time is 3,480 bags as shown by Table 6 . The cohort of 1-5 bags cumulatively accounted for approximately 2,013 bags, cohort of 6-10 bags totaled to 1,192 bags, cohort of 11-15 bags totaled to 247 bags and cohort of 0 - 1 bag totaled to 28 bags.

\begin{tabular}{|c|c|c|c|c|}
\hline \multicolumn{2}{|c|}{ No. Of Bags } & \multicolumn{2}{|c|}{ Charcoal Producers } & \multirow{2}{*}{$\begin{array}{c}\text { Total No. of Bags of } \\
\text { Charcoal }\end{array}$} \\
\hline Cohort & Average & $\%$ Of 895 & No. Of Producers & \\
\hline $0-1$ & 0.5 & 6.3 & 56 & 28 \\
\hline $1-5$ & 3 & 75 & 671 & 2,013 \\
\hline $6-10$ & 8 & 16.7 & 149 & 1,192 \\
\hline $11-15$ & 13 & 2 & 19 & 247 \\
\hline Total & - & 100 & 895 & 3,480 \\
\hline
\end{tabular}

Table 5: Bags of Charcoal Produced Per Event within Koibatek Forests Zone

Source: Field Survey, 2015

Table 6 shows that the proportion of charcoal producers who did the activity once a month were $35.4 \%$; 2 times were $47.9 \%$; 3 times were $12.5 \%$ and 4 times were $4.2 \%$. Within the cohorts of producing less than 1 bag of charcoal at a time; 33.3\% did production twice a month, 33.3\% (3 times) and another 33.3\% (4 times). Of those who produced 1-5 bags of charcoal; $25 \%$ did the activity once a month, $62.5 \%$ (2 times) and $12.5 \%$ ( 3 times) while $100 \%$ of producers who produced between 11-15 bags did the activity only once per month (Table 6). Therefore, majority of the producers did charcoal production either twice a month (47.9\%) or once a month (35.4\%) within gazette forests of Koibatek Forest Zone.

\begin{tabular}{|c|c|c|c|c|c|}
\hline \multirow{2}{*}{$\begin{array}{c}\text { Bags Charcoal Per } \\
\text { Event }\end{array}$} & \multicolumn{4}{|c|}{ \% Within The Times Per Month } & \multirow{2}{*}{ Total } \\
\cline { 2 - 5 } & 1 & 2 & 3 & 4 & \\
\hline $0-0.99$ & - & $33.3 \%$ & $33.3 \%$ & $33.3 \%$ & $100.0 \%$ \\
\hline $1-5$ & $38.9 \%$ & $47.2 \%$ & $11.1 \%$ & $2.8 \%$ & $100.0 \%$ \\
\hline $6-10$ & $25.0 \%$ & $62.5 \%$ & $12.5 \%$ & - & $100.0 \%$ \\
\hline $11-15$ & $100.0 \%$ & - & - & - & $100.0 \%$ \\
\hline Total & $35.4 \%$ & $47.9 \%$ & $12.5 \%$ & $4.2 \%$ & $100.0 \%$ \\
\hline
\end{tabular}

Table 6: Percent of Charcoal Producers on Monthly Frequency of Charcoal Production Source: Field Survey, 2015

Table 7shows that the monthly charcoal production within gazette forests of Koibatek Zone was about 6,144 bags. Most of these charcoal (3408.8 bags) was produced by producers who undertook the activity twice a month while the least (262.5 bags) were produced in four events per month. Production events of between 1-5 bags per event cumulatively accounted for 3,579 bags of charcoal per month while events that produced 6-10 bags accounted for 2, 235 bags per month. Therefore, the study established that it was easy to produce more charcoal within gazette forests by undertaking two events per month with each event producing between 1-5 bags.

\begin{tabular}{|c|c|c|c|c|c|}
\hline \multirow[t]{2}{*}{ Cohorts of Bags of Charcoal } & \multicolumn{4}{|c|}{ BAGS of Charcoal Per Month } & \multirow[t]{2}{*}{ Total } \\
\hline & 1 & 2 & 3 & 4 & \\
\hline $0.1-0.99$ & 0 & 18.5 & 27.7 & 37.0 & 83 \\
\hline $1-5$ & 783 & 1900.3 & 670.3 & 225.5 & 3,579 \\
\hline $6-10$ & 298 & 1490.0 & 447.0 & 0 & 2,235 \\
\hline $11-15$ & 247 & 0 & 0 & 0 & 247 \\
\hline TOTAL & 1,328 & $3,408.8$ & 1,145 & 262.5 & 6,144 \\
\hline
\end{tabular}

Table 7: Approximate Number of Bags of Charcoal Produced per Month

Source: Field Survey, 2015 
According to Ndegwa (2010), the average weights of charcoal packed in a standard bag is $40 \mathrm{~kg}$. Therefore, the estimated weight of the 6,144 bags of charcoal produced within the gazette forest blocks within Koibatek Forests Zone per month was 245,760 kg. Assuming that the volume of charcoal produced remained constant in the entire period of 108 months between January 2006 and December, 2014); then the total weight of charcoal produced within gazette forests was approximately $26,542,080 \mathrm{Kgs}$. The study converted the weights $(\mathrm{kg})$ into volume $\left(\mathrm{m}^{3}\right)$ by utilizing Openshaw (1978) which stated that $1 \mathrm{~m}^{3}$ of charcoal from preferred tropical hardwoods weighs $180 \mathrm{~kg}$. Therefore, the estimated volume of $26,542,080 \mathrm{kgs}$ (or 26,542.08 tonnes) of charcoal was 147,456 $\mathrm{m}^{3}$.

The results show that larger volume of charcoal $\left(147,456 \mathrm{~m}^{3}\right)$ was produced compared to that of firewood $\left(113,290.1 \mathrm{~m}^{3}\right)$ within gazette forests of Koibatek Forest Zones between 2006 and 2014. The results conforms to the findings of MoE (2002) that reported that charcoal production from Kenyan forests stood at 16,506,498 tonnes which was more than firewood whose volumes were 15,111,180 tonnes. Hillring (2006) in justifying why charcoal was more than firewood stated that most of the wood extracted for woodfuel is processed to charcoal so as to make transportation more efficient and increase the energy value.

\subsubsection{Forest Canopy Equivalent for Woodfuel Extracted between 2006 and 2014}

According to World Bank (2009), 82,192 $\mathrm{m}^{3}$ of wood required to produce charcoal or for firewood is equivalent to wood contained by a closed canopy of mature trees contained in 342.5 hectares of a forest. Therefore, $113,290.1 \mathrm{~m}^{3} \mathrm{of}$ firewood was extracted from gazette forests of Koibatek Zone between 2006 and 2014 translated to an approximated 472.1 ha of the gazette forests as deduced from World Bank (2009). Given that the total area of the gazette forests within Koibatek Zone was 51,007.7 hectares, $0.9 \%$ of the forests were consumed by firewood extraction between 2006 and 2014. The equivalent gazette forests area required for firewood extracted within each of the eight gazette forests blocks was: Koibatek block (131.3 ha), Maji Mazuri (94.7 ha), Esageri (70.4 ha), Narasha (63.6 ha), Chemususu (45.0 ha), Kiptuget (32.4 ha), Chemorgok (17.4 ha) and Sabatia (17.3 ha). Table 33 shows the equivalent percentage area the gazette forests blocks for firewood extracted between 2006 and 2014

\begin{tabular}{|c|c|c|c|}
\hline Gazetted & Total Gazetted & \multicolumn{2}{|c|}{ Forest Equivalent Of Firew ood (2006-2014) } \\
\cline { 3 - 4 } Forest Blocks & Forest(Ha) & Area in Ha & \% of the forest block \\
\hline Chemorgok & $5,851.5$ & 17.4 & 0.3 \\
\hline Chemususu & $11,304.8$ & 45.0 & 0.4 \\
\hline Narasha & $6,159.4$ & 63.6 & 1.0 \\
\hline Maji Mazuri & $6,065.0$ & 94.7 & 1.6 \\
\hline Sabatia & $4,108.0$ & 17.3 & 0.4 \\
\hline Esageri & $7,797.5$ & 70.4 & 0.9 \\
\hline Kiptuget & 850.0 & 32.4 & 3.8 \\
\hline Koibatek block & $8,871.5$ & 131.3 & 1.5 \\
\hline Total & $51,007.7$ & 472.1 & 0.9 \\
\hline
\end{tabular}

Table 8: Area and Percent of Forests Equivalent of Firewood Extracted Between 2006 and 2014 Modified From KFS (2011)

Table 8 shows that Kiptuget forest block was the most affected by firewood extraction with $3.8 \%$ of its area equated to firewood extracted from 2006 to 2014 followed by Maji Mazuri block (1.6\%) and Koibatek block (1.5\%). The least affected was Chemorgok block with only $0.3 \%$ of its area equated to the firewood extracted. The findings strengthen the argument by FAO (2006) that nearly a quarter of the tropical rainforest biome has been removed by humans due to woodfuel extraction and lumbering.

On the other hand, the estimated 147,456 $\mathrm{m}^{3}$ of charcoal produced within Koibatek forests Zone between 2006 and 2014 using traditional kilns whose efficiency was 20\% (World Bank,2009 and KFS (2009)meant that 823,247 $\mathrm{m}^{3}$ of wood was consumed in the charcoal burning activities. The wood consumed was equivalent to mature trees contained that contained in 3,430.5 hectares of closed canopy forests. Therefore, the area of closed canopy of forests required by charcoal production equates to approximately $6.7 \%$ of the total gazette forests of Koibatek Forests Zone.

\subsubsection{Forest Cover Change Linked To Woodfuel Extraction between 2006 and 2014}

The paper established that the totalarea of gazette forests closed canopy cover lost due to woodfuel i.e. firewood and charcoal extraction between 2006 and 2014 was 3,902.6 hectares. The area was equivalent to $7.6 \%$ of the gazette forests area of total $51,007.7$ hectares. However, according to FAO (2000) forests are capable of regenerating naturally or through intervention by man in establishing forests plantation. Thus, the ideal $7.6 \%$ loss due to wood fuel in gazette forests cover over a period of 9 years is difficult to be accounted for in change detections maps of forests.

The cumulative changes in closed canopy forests and non-forest such as grasslands, water cover and agricultural land cover within the gazette forests of Koibatek Zone detected within the two periods of 2006-2010 and 2010-2014 is indicated in Table 9. 


\begin{tabular}{|c|c|c|c|c|}
\hline & \multicolumn{2}{|c|}{$\begin{array}{c}\text { Change in 1st Period } \\
\text { (2006-2010) }\end{array}$} & \multicolumn{2}{c|}{$\begin{array}{c}\text { Change in 2nd Period } \\
\text { (2010-2014) }\end{array}$} \\
\hline Land Cover & Area (ha) & $\%$ & Area(ha) & $\%$ \\
\hline Closed Forests & 4032.63 & 5.65 & -1635 & -2.20 \\
\hline Open lands, grasslands and water & -4032.63 & -11.36 & 1635 & 4.94 \\
\hline
\end{tabular}

Table 9: Forest Cover Change within Gazetted Koibatek Forests Zone

Source: Field Survey, 2015

Table 9 shows that there was a significant increase of 5.65\% ( 4032.63 ha) in cover of closed forests between 2006 and 2010. This meant that $11.36 \%$ of non-forest decreased that period. However, in the period between 2010 and 2014, there was a decrease of the forest cover by $2.2 \%$ (1635ha) indicating an increase of $4.94 \%$ in the total area of non-forest. Therefore, in the period between 2006 and 2010, there was afforestation or regeneration of $5.65 \%$ and in the period between 2010 and 2014 there was deforestation of $2.2 \%$. An analysis of firewood extraction alone within the two periods i.e. 2006-2010 and 2010-2014 reveals that, woodfuel extraction played a role in the decline in cover of gazette forests of Koibatek Forests Zone. For instance, in the period between 2010 and 2014 (the period where deforestation by $2.2 \%$ occurred) total volume of woodfuel extraction was $67,378.8 \mathrm{~m}^{3}$ (Table 10) which was an increase from $58,837.5 \mathrm{~m}^{3}$ for the previous period of between 2006 and 2010 (Table 11).

\begin{tabular}{|c|c|c|c|c|c|c|}
\hline \multirow{2}{*}{ Forest Block } & \multicolumn{7}{|c|}{ Volume of Firew ood (M) from 2006- 2010 } \\
\cline { 2 - 7 } & 2006 & 2007 & 2008 & 2009 & 2010 & TOTAL \\
\hline Chemorkok & 813.57 & 664.09 & 365.75 & 255.56 & 405.83 & 2.504 .8 \\
\hline Chemususu & 276.7 & 521.39 & 180.77 & 147.46 & 400.3 & $1,526.62$ \\
\hline Narasha & 3307.92 & 2132.2 & 517.23 & 2627.46 & 1762.96 & $10,347.8$ \\
\hline Maji Mazuri & 3061.21 & 3625.44 & 1828.12 & 2631.86 & 1602.23 & $12,748.9$ \\
\hline Sabatia & 721.42 & 366.3 & 332.66 & 1190.56 & 465.54 & $3,076.48$ \\
\hline Esageri & 2970.69 & 3277.22 & 1429.02 & 604.46 & 1555.12 & $9,836.51$ \\
\hline Koibatek block & 1493.61 & 2888.88 & 1588.03 & 2613.7 & 6186.07 & $14,770.3$ \\
\hline Kituget & 1159.34 & 1363.73 & 300.58 & 653.86 & 548.65 & $4,026.16$ \\
\hline Total & $13,804.46$ & $14,839.25$ & $6,542.16$ & $10,724.92$ & $12,926.70$ & $58,837.5$ \\
\hline
\end{tabular}

Table 10: Annual Volume of Firewood Extracted between 2006 and 2010

Source: Field, 2015

\begin{tabular}{|c|c|c|c|c|c|c|}
\hline \multirow{2}{*}{ Forest Block } & \multicolumn{7}{|c|}{ Volume of Firew ood (M $\mathbf{M}^{3}$ from 2010-2014 } \\
\cline { 2 - 7 } & 2010 & 2011 & 2012 & 2013 & 2014 & TOTAL \\
\hline Chemorkok & 405.83 & 442.56 & 426.69 & 323.21 & 484.37 & $2,082.66$ \\
\hline Chemususu & 400.3 & 1972.08 & 2703.75 & 2363.26 & 2245 & $9,684.39$ \\
\hline Narasha & 1762.96 & 2209.66 & 1196.21 & 788.38 & 711.09 & $6,668.30$ \\
\hline Maji Mazuri & 1602.23 & 1315.08 & 3200.94 & 3560 & 1899.51 & $11,577.8$ \\
\hline Sabatia & 465.54 & 177.47 & 466.6 & 99.17 & 329.2 & $1,537.98$ \\
\hline Esageri & 1555.12 & 1757.88 & 2802.59 & 866.48 & 1623.24 & $8,605.31$ \\
\hline Koibatek block & 6186.07 & 2277.42 & 8357.33 & 3814.66 & 2287.33 & $22,922.8$ \\
\hline Kituget & 548.65 & 622.92 & 1579.45 & 902.23 & 646.34 & $4,299.59$ \\
\hline Total & $12,926.7$ & $10,775.07$ & $20,733.56$ & $12,717.39$ & $10,226.08$ & $67,378.8$ \\
\hline
\end{tabular}

Table 11: Annual Volume of Firewood Extracted between 2010 and 2014

Source: Field Survey, 2015

The results indicate an increase of 8,541.3m $\mathrm{m}^{3}$ in firewood extracted in 2010-2014 period where deforestation of $2.2 \%$ occurred compared to that of 2006-2010 period.This shows that part of the deforestation which occurred in the period is attributable to the increased in volume of firewood extracted.

\subsection{Effects of Woodfuel on Distribution of Preferred Trees Species}

\subsubsection{Preferred Trees Species for Woodfuel}

Table 13 shows the common exotic tree species preferred for both charcoal and firewood within the gazette plantations forests of Koibatek Forests Zone. 


\begin{tabular}{|c|c|c|}
\hline Scientific Names & Common/ Local Name & \% of The Total Respondents \\
\hline Cupressus lusitanica & cypress & 74.7 \\
\hline Pinus radiata & Pine & 56.0 \\
\hline Grevillea robusta & Silky oak & 33.9 \\
\hline Eucalyptus grandis & Blue gum & 24.2 \\
\hline Casuarina cunninghamiana & Casuarina & 14.8 \\
\hline
\end{tabular}

Table 12: Exotic Trees Species Preferred for Firewood and Charcoal

Source: Field Survey, 2015

The exotic tree species extracted for firewood and charcoal were: Cupressus lusitanica as reported by $74.7 \%$ of the total respondents, Pinus radiate (56\%), Grevillea robusta $(33.9 \%)$, Eucalyptus grandis $(24.2 \%)$ and Casuarina cunninghamian (14.8\%)(Table 13). Therefore, Cupressus lusitanica (cypress) and Pinus radiate (pine) tree species were the most preferred exotic tree species extracted while Casuarina cunninghamian was the least preferred species of the reported tree species. The results of the study concur with KEFRI (2014) which reported that the major uses of tree species such as Cupressus lusitanica, Eucalyptus spp, Pinus radiate and Grevillea robustais timber or poles,firewood and charcoal.

Table 14 on the other hand shows eight (8) indigenous tree species within gazette forest blocks of Koibatek Forests Zone preferred for firewood and charcoal. The most preferred tree species was Tarchonanthus camphoratus known locally in tugen language as lelechwet reported by(81.3\%) of the respondents and maregeiwet (Kipsigis language) reported $61.2 \%$ of the respondents. Other indigenous tree species used for firewood and charcoal were: Thalictrum rhynchocarpum (33.9\%), Podocarpus falcatus (31.3\%), Olea africana(24.0\%)Juniperus procera (20.8\%), Acacia polyacantha (10.4\%), and Croton megalocarpus (7.8\%).

\begin{tabular}{|c|c|c|}
\hline Scientific Names & Common Name & \% of The Total Respondents \\
\hline $\begin{array}{c}\text { Tarchonanthus } \\
\text { camphoratus }\end{array}$ & lelechwet (tugen) & 81.3 \\
\hline $\begin{array}{c}\text { Thalictrum } \\
\text { rhynchocarpum }\end{array}$ & Maregeiwet (Kipsigis) & 61.2 \\
\hline Podocarpus falcatus & Yellow wood & 33.9 \\
\hline Olea africana & Wild olive-emtit & 31.3 \\
\hline Juniperus procera & E.A cedar, Mtarakwa & 24.0 \\
\hline Acacia polyacantha & Falcons-claw acacia & 10.8 \\
\hline Croton megalocarpus & Otonwo (tugen) & 7.8 \\
\hline
\end{tabular}

Table 13: Indigenous Tree Species Preferred for Firewood and Charcoal Field Survey, 2015

FGDs (2015) revealed to the study that most of the licencees with MFLs preferred indigenous tree species to exotic species. FAO (2003) agrees with the results as it stated that, although practically all tree species could be used for firewood, there is a group of tree species that is generally preferred because they usually burn without excessive smoke and unpleasant odours. Among the indigenous species, the most widely used tree species in the different countries is Acacia sppwhile exotictree species that are being grown for firewood include Eucalyptus spp., C. cunning hamiana and Acacia mearnsii. Pines and cypresses although often used in areas of high wood deficit are not preferred species.

\subsubsection{Level of Extraction of Preferred Trees Species for Woodfuel}

Table 12 shows the level of extraction of both indigenous and exotic tree species by charcoal producers and firewood extractors within gazette forests of Koibatek Forests Zone.

\begin{tabular}{|c|c|c|c|c|}
\hline \multirow{2}{*}{$\begin{array}{c}\text { Sections Of } \\
\text { Gazette Forests }\end{array}$} & \multicolumn{2}{|c|}{$\begin{array}{c}\text { \% Responses On Species } \\
\text { Preferred For Firewood }\end{array}$} & \multicolumn{2}{c|}{$\begin{array}{c}\text { \% Response On Species Preferred } \\
\text { For Charcoal Burning }\end{array}$} \\
\cline { 2 - 5 } & Indigenous & Exotic & Indigenous & Exotic \\
\hline Natural & 42.3 & 5.3 & 34.8 & 4.3 \\
\hline Plantations & 9.3 & 43.1 & 4.3 & 56.5 \\
\hline Total & 51.6 & 48.4 & 39.1 & 60.9 \\
\hline
\end{tabular}

Table 14: Responses on the Preferred Tree Species for Firewood and Charcoal Source: Field Survey, 2015

Table 12 shows that $51.6 \%$ of woodfuel extractors preferred firewood from indigenous tree species of which 42.3\% from natural forests and $9.3 \%$ from plantation forests. $48.4 \%$ of the extractors preferred firewood from exotic tree species of which $43.1 \%$ was sourced from plantations and $5.1 \%$ sourced from natural forests. On the other hand, $39.1 \%$ of charcoal producers preferred indigenous species while $60.9 \%$ preferred exotic species. Therefore, more firewood extractors preferred indigenous tree species compared to exotic tree species while charcoal producers preferred exotic 
tree species compared to indigenous tree species. Personal communications by Forest Officers (2016) supported the findings by stating that, though Monthly Fuel Licenses had no restrictions on the sections of the forest from which firewood was collected, most woodfuel extractors preferred indigenous species. According to the FGD participants, indigenous tree species provided good quality woodfuel and produced less smoke during burning. In addition, tree species such as Olea Africanaand Tarchonanthus camphoratus had the capability to burn efficiently even when wet (high moisture content).

Figure 2 shows that $66 \%$ of woodfuel extractors reported that the preferred tree species for woodfuel were not the dominant species within the gazette forests while $34 \%$ of the extractors reported that the species were the dominant species. Therefore, woodfuel extraction leads to reduction in the number of tree species preferred for wood fuel within gazette forests since were not the dominant species of the forests.

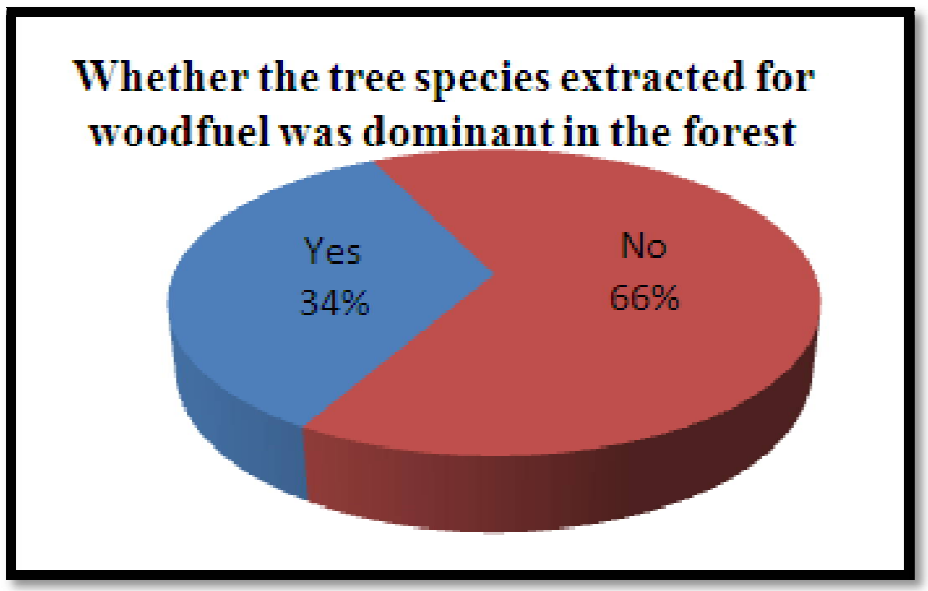

Figure 2: Tree Species Dominance within the Gazette Forests Source: Field Survey, 2015

\begin{tabular}{|c|c|c|c|c|}
\hline \multirow{2}{*}{$\begin{array}{c}\text { Species of } \\
\text { trees }\end{array}$} & \multicolumn{4}{|c|}{ \% responses on change in distribution due to woodfuel extraction } \\
& \multicolumn{4}{|c|}{ from 2006-2014 } \\
\cline { 2 - 5 } & Increased & Decreased & No Change & Total \\
\hline Indigenous & 7 & 89 & 4 & 100 \\
\hline Exotic & 9 & 23 & 68 & 100 \\
\hline Mean & 8 & 56 & 36 & 100 \\
\hline
\end{tabular}

Table 15: Changes in Distribution of Preferred Tree Species between 2006 and 2014

Source: Field Survey, 2015

Table 15 indicates that between 2006 and 2014,56\% of woodfuel extractors indicated that distribution of preferred tree species for woodfuel decreased, $36 \%$ reported that there were no changes and $8 \%$ indicated that trees species had increased. It was also noted that indigenous tree species within gazette forests decreased due to woodfuel extraction as indicated by $89 \%$ of woodfuel extractors. For exotic species, $68 \%$ of the total woodfuel extractors reported a no change in their distribution within gazette forests. According to Cardoso et al (2015) most indigenous tree species are preferred because they have high calorific value and low moisture contents compared to most exotic species. Cardoso et al (2015) also agrees with findings that distribution of exotic species did not change since it stated that exotic species are fast growing species planted for various purposes such as shelter, shade, fodder, and fence posts, ornamental and forfirewood. FAO (2003) in supporting preference of exotic species for woodfuel reported that pines and cypresses are often used in areas of high wood deficit, however, are not preferred species.

\section{Conclusions}

The paper concludes that woodfuel extraction within a period of 9 years between 2006 and 2014 was equivalent to $7.6 \%$ loss in forest cover of gazette forests. Charcoal production accounted for $6.7 \%$ of the loss in forest cover while firewood extraction accounts for $0.9 \%$ loss in forest cover. The higher loss of forest cover associated with charcoal burning was mainly caused by the use of traditional kilns whose efficiency $20 \%$. The cumulative deforestation caused by firewood and charcoal results from the reduction in distribution of approximately 13 trees species mostly preferred for firewood and charcoal extraction. Five (5) of the tree species preferred for woodfuel were exotic species within plantation forests while 8 are indigenous species within natural forests.

\section{Recommendations}

The potential wood equivalent from standing tree stands within both natural and plantations forests should be calculated or measured. This will ensure monitoring of level of exploitation based on extraction permits issued by management authorities. Additionally, the preferred tree species for wood fuelgazette forests should be protected and or sustainable extraction plans such as temporal closures and ban of cutting of standing trees for woodfuel be developed and implemented. Accurate forest inventory of the existing tree species should also be kept and monitoring of the trends on 
distribution of these species be done regularly. Tree species that endangered by woodfuel extraction must be identified and protected.

\section{References}

i. Abd'razack, T.A (2013). Wood Fuel Consumption and Ecological Footprint of African Cities; International Journal of Education and Research Vol.1 No.2 February 2013.

ii. Agarwala, P., (2006): Environmental Studies. Alpha Science International Ltd, London

iii. Cardoso, B., Ladio, H. A., Dutrus, S., and Lozada, M., (2015). Preference and calorific value of fuelwood species in rural populations in northwestern Patagonia; https:/ / www.journals.elsevier.com/

iv. Du Plessis Morne A., (1994). The effects of Fuelwood Removal on the Diversity of some Cavity-Using Birds and Mammals in South Africa; Fitzpatrick Institute, University of Cape Town, South Africa.

v. Energy Sector Management Assistance Program (ESMAP), (2012). Commercial Woodfuel Production: Experience from Three Locally Controlled Wood Production Models

vi. Ewaso Ngiro South Development Authority (ENSDA), (2005). Maasai Mau Forest Status Report 2005: Ewaso Ngiro South Development Authority, Narok, Kenya <http:/ / www.iapad.org/ publications/ >

vii. Food and Agriculture Organization (FAO), (2000). Forestry Outlook Study for Africa; FAO Forestry Paper 141, FAO for the UN, Rome.

viii. Food and Agriculture Organization (FAO), (2003). State of Forest and Tree Genetic Resources in Dry Zone Southern Africa Development Community Countries; Forestry Department of FAO, Rome, Italy

ix. Food and Agriculture Organization (FAO), (2005). Global Forest Resources Assessment 2005, Progress towards sustainable forest management, p.107-108; FAO, Rome.

x. Forestry Society of Kenya (2010). Forest for Agriculture, Energy and Water; Forestry Society of Kenya, Nairobi, Kenya.

xi. Gevorkiantz S.R., and Olsen, L.P., (1955). Composite Volume Tables for Timber and their Applications in the Lakes States; U.S Department of Agriculture, Washington DC

xii. International Union for Conservation of Nature (IUCN), (2008). Supporting the wisdom of age for effective community forest management; IUCN, Nairobi, Kenya.

xiii. Kenya Forest Service (KFS), (2014). KFS Strategic Plan 2014-2017; accessed at www.kenyaforestservice.org on $4^{\text {th }}$ December, 2016

xiv. Kenya Forest Service (KFS)-Koibatek, (2011). Annual Report, Koibatek Forests Zone 2011; Kenya Forest Service, Nairobi, Kenya.

xv. Kenya Forestry Research Institute (KEFRI), (2014).Useful Trees Suitable For Central Highlands Eco-Region; KEFRI, Kenya.

xvi. Leach, G. and Mearns, R., (1988). Beyond the Wood Fuel Crisis: People, Land and Trees in Africa; Earthscan Publishers. London

xvii. Martinez-Alier, J., (1995). Energy and Power, Alternative energy and its implications; Nuclear Monitor Issue \#427-428

xviii. Nellie, O., and Githiomi, J., (2009). Forest Energy for Livelihoods; A paper presented in the 4th Forestry Society of Kenya Scientific Conference November 2009.

xix. Patmos, M., (2005). Estimating Firewood from Standing Trees; University of New Hampshire Cooperative Extension; USA

xx. Soussan, J., (1988). Primary Resources and Energy in the Third World; Routledge, London.

xxi. United Nations Economic and Social Council (UN ECOSOC), (2017). Report of the United Nations Forum on Forests on its 2017; Special session; 20 January 2017,E/ 2017/ 10-E/CN.18/ SS/ 2017/ 2: New York

xxii. World Bank, (2009). Environmental Crisis or Sustainable Development Opportunity? Transforming the Charcoal Sector in Tanzania: A policy Note March 2009; World Bank, Washington DC 20433, USA 